\title{
THE PLACE OF THEOLOGICAL EDUCATION IN THE PREPARATION OF MEN AND WOMEN FOR THE BRITISH BAPTIST MINISTRY THEN AND NOW
}

\author{
ANTHONY R. CROSS * \\ International Baptist Theological Study Centre, Amsterdam
}

\begin{abstract}
Using principally, though not exclusively, the learning of the biblical languages, this paper seeks to demonstrate four things. Firstly, from their beginnings in the early seventeenth century the majority of British Baptists have believed that the study of theology is essential for their ministers, and that the provision of such an education through their colleges is necessary for the well-being of the churches. Secondly, and contrary to misconceptions among Baptists and those of other traditions, Baptists have always had ministers who have been highly trained theologically, and that this has enriched their service as pastors. Thirdly, it reveals that Baptists today have a wealth of both academically-gifted and theologically-astute pastortheologians and pastor-scholars. Finally, it argues that theology has always played its part in the renewal of Christian life and witness for which so many Christians today are praying.
\end{abstract}

KEY WORDS: Baptists, ministerial theological education, biblical languages, renewal

\section{Introduction}

I feel a sense of urgency about this subject, as the amount of time allotted to theological study within education for the Baptist ministry has lessened markedly_some feel drastically-from full-time to part-time, and sometimes even less, and sometimes now not even at a Baptist college or recognised theological college. Much of present-day British Baptist life does not emphasise the necessity of theology for ministerial formation or Christian discipleship in the way it has for over 400 years (Cross 2016). Much contemporary British culture does not place a high premium on education, and this pattern is undoubtedly mirrored among the churches. This often results in the dangerously erroneous view that theology is unimportant, and even a distraction, from the real task not of ministry, but what is increasing-

ANTHONY R. CROSS (PhD 1997, University of Keele, United Kingdom) is an Adjunct Supervisor at The International Baptist Theological Study Centre, Amsterdam. Email: jlarcross@aol.com. 
ly seen as leadership, with its clear basis in managerial theory, and not biblical-theological study. It also often leads to believing in theology's irrelevance for mission. So churches' attitude to the Baptist colleges has become one of indifference, and consequently they stop supporting them. This last observation raises the question why they have stopped, and this itself is a theological question which involves ministry and the support of those called to pastoral and evangelistic ministries (cf. Luke 10:7, and 1 Timothy 5:18), stewardship, discipleship, which always involves learning (cf. Matthew 10:29).

In To Communicate Simply You Must Understand Profoundly (Cross 2016), I set out a detailed, referenced, and sourced study which refutes claims that Baptists came late and unevenly to the conclusion that theological education is essential to a vital ministry. I argue that theology is as essential to the health and well-being of the churches and their mission today as it has ever been. It also sets out to show Baptists how central the study of the Bible and theology has been, and should continue to be, in the preparation of ministers, and, by extension, in the discipleship of all believers. Further, it sets out the case for the recovery of theology to its central role in ministerial preparation.

The purpose of this paper, therefore, is to survey briefly the place and significance of theological education in the preparation of ministers in the over 400 year history of British Baptists. As a Christian tradition whose origins lie in the reforms of both belief and practice enacted by a group of English Puritan Separatists as their faithful response to their reading of scripture, and who, ever since, have professed that their life and thought are grounded in the Bible and reflection upon it-which is what theology is-it might, perhaps, appear to be a strange subject for study. However, as so often, there is frequently a tension between what people say they believe and do, and what they actually believe and do.

\section{Theological Study in the Life of the Church}

Contrary to misconceptions among Baptists and those of other traditions, Baptists have always had men, and in time also women, who have been highly trained theologically, and made significant contributions to the various theological disciplines-and I believe that there are more of them today than there have ever been (Cross 2016: 231-369). If this is so, then the fact that the opportunities available to this increased number of pastor-scholars is indicative of a lack of discernment of the British Baptist tradition, its captivity to the prevailing pragmatism and comparative anti-intellectualism of so much of contemporary British society. It may also be a failure to heed the call to the need for scholarship made by so many of our tradition's most eminent men and women. Perhaps it even reflects a degree of unfaithfulness on the part of the denomination at large which has itself exhibited an 
ambivalent attitude towards scholarship, particularly in the last two to three decades, and this despite the avowed evangelicalism of many of those in prominent positions within the Baptist Union of Great Britain, with their claimed commitment to the centrality of scripture, discipleship and mission, as well as their emphasis on sound doctrine.

Yet the testimony of Baptist history has unequivocally been for the necessity of strong theological foundations for gospel preaching, the deepening of discipleship, and effective mission work. This is evidenced in the fact, for example, that the founding of both the Baptist Missionary Society (BMS) and Home Mission work at the end of the eighteenth and beginning of the nineteenth centuries was driven by the theological renewal led by The Bristol Tradition of Bernard Foskett, Hugh and Caleb Evans, the tradition in the North of England championed by Alvery Jackson and John Fawcett, the theology of the Midland Baptist Robert Hall Sr, and the impact of the theology of Jonathan Edwards on the Northamptonshire Baptists, chiefly John Ryland Jr, John Sutcliff, Andrew Fuller, William Carey, and their Midland friend Samuel Pearce (Cross 2017).

Why are such pastor-theologians needed? The answer is simple. No one can rightly handle or use something they simply do not understand, for, as Peter Cotterell puts it: 'To communicate simply you must understand profoundly' (Randall 2000: 243). Such pastor-theologians are there to help the church grow in its understanding and enable its better handling of God's word. For, as the apostle Peter exhorts all Christians, 'grow in the grace and knowledge of our Lord and Saviour Jesus Christ', so that to him will be 'the glory both now and to the day of eternity. Amen' (2 Peter 3:18).

To illustrate our argument, the learning of the biblical languages will be a major, though by no means exclusive, focus of attention of this paper. This brings us conveniently to the Bible, which, Baptists assert, is the word of God and the basis for their life and practice. Yet they can condemn those who search the scriptures academically, and especially those who arrive at different interpretations as a result of their studies-seen, for example, in the protracted and bitter controversies between Calvinistic/Particular and Arminian/General Baptists. This state of affairs has been well summarised by Bill Leonard when he observes that British Baptist concern for education has been paradoxical, in that while many have promoted education others have 'remained suspicious of its benefits' (Leonard 2003: 143). Such people are not only in our churches, but also among the students training for ministry in its various forms, but also, it seems, may even include some teachers in our colleges who minimise the benefits of theology (Murray 2004: 300302).

So what about 'theology'? What do we understand by this word, which so many Baptist Christians, and Christians of other traditions, dismiss, ridi- 
cule, fear, denigrate, and even treat as a hindrance to the life of the church and the work of God's kingdom? According to John Colwell, 'theology, throughout all its various sub-disciplines, remains theology; and theology is simply the study of God' (Colwell 2005: 1, italics added). Bruce Milne expands this: 'Theology literally means «the science of God), or more fully, «thought and speech which issue from a knowledge of God>(cf. 1 Corinthians 1:5)' (Milne 1982: 11). As such theology is not to be identified with the academic discipline of theology, what used to be called divinity, though, of course, it often involves it, and certainly benefits from it.

In his widely used Know the Truth, Milne begins this popular handbook of Christian belief with the self-deprecating but rather superficial exclamation: 'Of course, I'm no theologian'. He continues,

How often have I heard that comment over the years, not infrequently from those who ought to know better. It usually implies that serious thinking about Christian beliefs and the attempt to express them in an ordered form is altogether distinct from real Christianity, which is about practical concerns: our personal walk with the Lord, sharing the gospel, and so on. While the theologians may have their place, the serious study of doctrine is seen as something which need not bother ordinary Christians, and may even hinder their Christian life if they go into it too deeply.

This prevalent anti-doctrine spirit is a major departure from the Christian instincts of earlier ages and its roots go deep into contemporary Western culture. In face of the tremendous challenges and opportunities facing the church... this dismissal of doctrine is, in my judgment, nothing short of a recipe for disaster (Milne 1982:11).

In short, and 'as a matter of plain fact every Christian is a theologian!' But he does not stop there. Milne asserts that through being born again all Christians have begun to know God, 'that is, we all have a theology of sorts, whether or not we have ever sat down and pieced it together'. As a result, theology is 'everybody's business', not just the domain of 'a few religious eggheads with a flair for abstract debate'. Once this is grasped, 'our duty is to become the best theologians we can to the glory of God, as our understanding of God and his ways is clarified and deepened through studying the book he has given for that very purpose, the Bible (2 Timothy 3:16)' (Milne 1982: 11, italics added).

\section{Have Baptists Really Been Anti-Educational?}

In the 1923 first edition of his history of British Baptists, W. T. Whitley believed that in the latter half of the seventeenth century 
[t]he denomination was uncultured, and had no aspiration after culture. The fallacy gained ground that God set a premium on ignorance, that piety and education were barely compatible (Whitley 1923: 184, italics added).

However, the evidence of what the earliest Baptists both said and did is not as Whitley, and others who have followed him, have claimed. They have misread and misunderstood our story. The writings of Baptists, along with accounts of what Baptists have actually done, shows that they have usually sought to be as well-educated as they could. In fact, when deprived of the opportunity to study at an academy, seminary, college, or university many Baptist ministers educated themselves, many most successfully, and to the great benefit of the churches and kingdom of God. Self-education is still education, even if it is through the reading of the Bible and books, and through the practice of ministry.

For instance, it was reported that after Thomas Grantham had finished his tailor's apprenticeship he 'gave himself to study' becoming 'a great Proficient in Learning' (Firmin 1688: $\mathrm{A}^{\mathrm{v}}$ ). This is borne out by the large number and significance of the works Grantham published (Bass 2013: 24-34 and passim; Essick 2013: 34-54 and passim). Though the General Baptist Richard Allen 'had not the advantages of a learned education', like Grantham he rectified this 'by his own industry, after he was called to the work of the ministry', attaining 'to such an acquaintance with the oriental languages, and other parts of useful learning, as to exceed many who enjoyed the benefits of a learned education in the schools' (Crosby 1738-40, volume 4: 346, italics removed). The Seventh Day Baptist, Joseph Stennett, was educated at Wallingford grammar school and also by his father, Edward (1627 / 281705), a physician, and his brother, Jehudah, who himself published a Hebrew grammar in 1685 (Stennett 1685). Joseph Stennett knew a variety of ancient and modern languages, including Hebrew, Greek, Latin, French, and Italian (Crosby 1738-40: 4.320). Over time, Baptists became almost synonymous with knowledge of the biblical languages, such that Bishop A.C. Headlam once remarked that 'only Baptist ministers and regius professors know Hebrew and both are slightly mad' (West 1983: 200). The Particular Baptists' most accomplished self-educated ministers included John Fawcett, Robert Robinson, William Carey, Charles Haddon Spurgeon, and Andrew Fuller (Cross 2016).

The origins of the Bristol Academy (founded 1720) lie in Edward Terrill's deed of gift dated 3 June 1679. Terrill was an elder in the Broadmead church, Bristol, and passionately convinced of the need for ministers to be theologically educated and theologically competent, which entailed their skill in the biblical languages so that they would be enabled to preach the gospel and also train the next generation of ministers. His will made the following provision: 
For the use and subsistence of a holy learned man, well skilled in the tongues, to wit, Greek and Hebrew, and should profess and practice the truth of believers' baptism, as a pastor or teacher to the congregation aforesaid, and so to another after his death, successively, for ever... (Edward Terrell's Charity n.d.: 281).

The Seminary's 'plan of instruction' included 'the learned languages, so as to enable them to examine any passage of scripture in the original' (An Account of the Bristol Education Society 1770: x), and in so doing they would realise Hugh Evans' aim which he bequeathed to The Bristol Tradition,

not merely to form substantial scholars but as far as in him lay he was desirous of being made an instrument in God's hands of forming them, able, evangelical, lively, zealous Ministers of the gospel (Evans 1781: 31, italics added).

This vision was implemented by the Academy's first four Principals, Foskett, Hugh and Caleb Evans, and Dr John Ryland, and was passed on to their students, and through them the churches they served were built up. When combined with the theological work of those like Fawcett in the North, Robert Hall Sr and Samuel Pearce in the Midlands, and John Sutcliff and Andrew Fuller in Northamptonshire, the vision resulted in the renewal of Baptist life and witness in Britain, exemplified in Baptist foreign and home mission work (Cross 2017).

When the Bristol Education Society was formed in 1770 (An Account of the Bristol Education Society 1770: 1-7), its twofold purpose was 'the education of pious candidates for the ministry', and 'the encouragement of missionaries to preach the gospel wherever providence opens the door for it' (Evans 1775: 24). Caleb Evans, the driving force behind the Society, and himself an able linguist, who used Hebrew, Greek, and Latin in support of his argument (Evans 1779: passim), exhorted students 'to the vigorous pursuit of your other studies in general', because

$[w]$ hatever hath a tendency to enlarge our ideas of the divine perfections, to give us a clearer view of the meaning of Scripture and the evidences of its authenticity, or to enable us to speak and write our thoughts with propriety, perspicuity, and energy, is certainly well worth the attention of every candidate for the ministry (Evans 1770, volume 1: 346 , italics added).

John Ryland, who was such a key figure in the revival of the eighteenthcentury Baptists, and moulded the thinking of many of the early Baptist missionaries (Clipsham n.d.), was, by the age of five and a half, able to read Psalm 23 in Hebrew. By nine he had read the New Testament in Greek, and before the age of eleven and seven months had read Genesis in Hebrew five times (Culross 1897: 69-70). A highly gifted scholar, and, like his father John Collett Ryland, a linguist (e.g., Ryland 1777), Ryland taught, among 
other things, Hebrew (Ryland n.d.), Greek, Latin, theology, church history, and sacred antiquity (Moon 1979: 28). His work was motivated by the conviction that

though we readily allow it to be unnecessary for every minister to possess much of what is commonly called learning, yet, in the present day, when the advantages of education are more common among our hearers, we think it at least highly expedient that every large body of Christians should possess some learned ministers; and the greater their number and attainments the better (Ryland 1812: 18-19, italics added).

Speaking in 1822, William Staughton, the founder of the Philadelphia Education Society in 1812, and one of Ryland's students at Bristol, advocated a liberal education for all students which included proficiency in 'two languages, in addition to our maternal one', namely, Latin and Greek (Staughton 1822: 13). Later he maintained that

it is desirable that a public teacher be able to read the pages of inspiration in the languages in which they were written. Unacquainted with the construction of his mother tongue, with the history of the nations, with the economy of the earth and heavens, and with the science of composition, he must deplore the privation he suffers, when called to defend the truths which are dearer than life, in the presence of adversaries who have arrayed themselves in all the armour which learning can furnish... In the present age, when missionaries are passing into almost every region of the earth, it is evident that, to enable them with greater facility to acquire new languages, and to translate the scriptures from the original text, a sound and extensive education is not only desirable but necessary (Staughton 1822: 25-26, italics added).

Staughton recognised that as well as being of importance for preaching (both pulpit and itinerant) and evangelism (at home and abroad), education was also vital for Bible translation. Half a century earlier, John Gill expressed matters in a wonderfully frank way:

Here I cannot but observe the amazing ignorance and stupidity of some persons, who take it into their heads to decry learning and learned men; for what would they have done for a Bible, had it not been for them as instruments?... Bless God, therefore, and be thankful that God has, in his providence, raised up such men as to translate the Bible into the mother tongue of every nation, and particularly into ours; and that he still continues to raise up such who are able to defend the translation made, against erroneous persons, and enemies of the truth; and to correct and amend it in lesser matters, in which it may have failed, and clear and illustrate it by their learned notes upon it (Gill 1769, volume 1: 45, also quoted approvingly in An Account of the Constitution of the Bristol Education Society 1770: v-vi). 
This connection between education, mission, and Bible translation is nowhere better illustrated than in the life and ministry of William Carey and his colleagues. After coming to Baptist convictions, Carey continued his work as a cobbler, preaching in the surrounding area, while furthering his own education. He was taught Latin by John Sutcliff, but he also learnt the two biblical languages. He studied Hebrew with the help of John Ryland Jr. When he was called to minister at Moulton in 1785, he had to supplement his income by shoemaking and running a school, something he had to continue when he moved to his second pastorate, Harvey Lane Baptist Church, Leicester. The following year he completed his An Enquiry (1792), and the year after that he and his family went to Bengal, where he learned Bengali and Hindi, and began to preach in the vernacular. In 1794, Carey set up a school in Madnabati, North Bengal, a pattern he and other missionaries followed in India on a number of occasions, and when, six years later, he moved to Serampore, he joined Joshua Marshman and William Ward in the work there, and in 1818 they together founded Serampore College.

\section{'Human Learning under God': Examples from Baptist History}

Carey was not alone in running a school. Because the only two universities in the country, Cambridge and Oxford, were closed to Baptists until the nineteenth century, many ministers took the initiative and opened their own schools and, in time, academies and colleges. Academies were run, for varying lengths of time, in the homes of ministers. Among those who ran such academies were John Fawcett at Hebden Bridge, then Brearley Hall, and finally Ewood Hall, and he trained, among others, John Sutcliff, who is best known for issuing the Prayer Call in 1784 which eventually led to the founding of the BMS, and also William Ward, who went on to become one of the Serampore Trio. Sutcliff himself opened an academy, and he trained William Carey as an out-pupil, but also the minister of Charlotte Chapel, Edinburgh, and great supporter of the BMS, Christopher Anderson, as well as Carey's nephew, Eustace Carey.

In 1856, Spurgeon opened the Pastor's College, as it was originally known. From the beginning, the aim of the College was

to help preachers, and not to produce scholars. There are plenty of institutions for the promotion of learning for its own sake; ours is a part of the work of the church at the Tabernacle, and church-work is gospel-work, and nothing else. Let the world educate men for its own purposes, and let the church instruct men for its special service. We aim at helping men to set forth the truth of God, expound the Scriptures, win sinners, and edify saints. Hence it is important that men should be prayerful as that they should be studious, and as needful that they 
should be gracious in soul as healthy in body (Spurgeon 1889: 311, italics original).

His priority was clearly reflected in his statement, 'Let them become scholars if they can, but preachers first of all, and scholars only to become preachers' (Annual Paper concerning the Lord's Work 1870: 7). It is important that we note that Spurgeon did not equate scholars with theologians. As Ian Randall points out, Spurgeon was deeply committed to theological education, exclaiming, 'Be well instructed in theology, and do not regard the sneers of those who rail at it because they are ignorant of it. Many preachers are not theologians, and hence the mistakes which they make.' Implicitly, then, for Spurgeon the ideal minister was a theologian, because theology serves mission. He continued, 'It cannot do any hurt to the most lively evangelist to be also a sound theologian, and it may often be the means of saving him from gross blunders' (Spurgeon 1874, quoted in Randall 2007: 4; see also Spurgeon 2013). Spurgeon's goal, therefore, was in many ways very simple: 'When the Pastor's College was fairly moulded into shape, we had before us but one object, and that was, the glory of God by the preaching of the gospel' (Spurgeon 1962: 386; see Randall 2005: 16-19, on the importance of preaching).

Like so many before him, Spurgeon was seeking to walk the tightrope between too great an emphasis on learning and deprecating it. He admitted,

Time was when an educated ministry was looked upon by certain of our brethren as a questionable blessing, indeed it was thought that the less a minister knew the better, for there was then the more room for him to be taught of God. From the fact that God does not need man's wisdom it was inferred that he does need man's ignorance... (Spurgeon 1882).

From 1856 to 1878, forty-eight new churches were planted by Spurgeon's students (Stetzer and Im 2016: chapter 5), and even though Spurgeon understood pastors also to be evangelists he nevertheless called his College the Pastor's / Pastors' College, not the Evangelists' College (I am grateful to Dr Brian Haymes for this observation).

Over thirty years after founding the Pastors' College in 1856, and in line with the other colleges, Spurgeon was convinced that the study of the biblical languages was of paramount importance in his students' education and for their continuing ministry:

Every academy for helping students to the ministry must largely cultivate THE STUDY OF LANGUAGES. I need not plead for the sacred tongues, since no one will question the immense importance of reading the Scriptures in their original form. Sufficient Hebrew and Greek to be able to read the Old and New Testaments every 
man ought to acquire (Spurgeon 1887: 7, upper case emphasis original, italics added).

According to Hugh Evans, 'the importance and desireableness of human learning, may be further argued from the happy effects produced by it, when sanctified, and humbly devoted to the service of God'. This he illustrated with the English Bible, the result of 'human learning, under God', as well as 'for those valuable commentaries, and expositions of the scriptures, which have been so eminently useful to the people of God in every age-the excellent apologies which have been published in defence of Christianity, the elaborate treatises which have been wrote upon the various doctrines of the gospel, and other branches of our holy religion' which are 'to be ascribed, under God' to learning (Evans 1773: 18-20, italics original).

This tradition of Baptist linguists and pastor-scholars has been kept alive through the work of such Old Testament scholars as H. Wheeler Robinson, Theodore H. Robinson, H. H. Rowley, Aubrey R. Johnson, David S. Russell, Ronald E. Clements, and Rex A. Mason, and New Testament scholars, including George R. Beasley-Murray, R. E. O. White, Ralph P. Martin, Donald Guthrie, Peter Oakes, and Sean F. Winter. There also continue to be local church ministers who lay great store in knowing the biblical languages, have attained the highest levels of academic excellence and are rightly to be considered pastor-theologians. For instance, Tim Carter, minister at Brighton Road, Horsham, Robert Parkinson, minister at Didsbury Baptist Church, Manchester, and Simon Perry, Chaplain at Robinson College, Cambridge (for all these and more, see Cross 2016: passim).

But there were two other reasons why Spurgeon believed in 'the acquisition of a language'. First, the learning of, in particular Latin, was 'not so much for the sake of the books which you will read, as for the sake of the language itself'. For him, Latin was needed in order to 'know the meaning of English' because 'what anatomy is to surgery, ... the classical languages are to oratory', or 'what the tools in the shop are to the worker in wood or metal, that words are to the preacher, and in the apprenticeship of learning a language he discovers the use and value of those tools. Is not this a matter of prime importance?' (Spurgeon 1887: 7, italics added). His aim was to develop preachers of the gospel for which 'the medium of conveying the truth... is language, and therefore we ought to know the nature, and rule, and form, and composition of language in general, and of our mother-tongue in particular'. The acquisition of languages not only aided the unlocking of foreign languages, 'but that we may know the fabric of language itself'. Secondly, Spurgeon rejected those who sneered at and questioned the good of learning Latin and Greek, and added their importance for missionaries as they would make them more capable of acquiring foreign languages 'because he knows the way of the human tongue' (Spurgeon 1887: 7-8). 


\section{Ministerial Education to Be Passed on}

Theological education, however, is not just of benefit to ministers themselves. In an ordination charge to the Rev. William Belsher at Silver Street, Worcester, Dr John Ryland made plain that ministerial education is not an end in itself, but is to be passed on to the church. He states that guiding souls to heaven requires of the minister both knowledge and judgment, which includes acquaintance with the true character of God, and a knowledge of his holy laws. A pastor must also be able to instruct, for, he says: 'We must cultivate an extensive acquaintance with the whole revelation God has made of his will; and be able to direct the redeemed of the Lord, in all the ways of holiness and righteousness, in which they should walk before him...' To this end, Ryland prayed that the spirit of judgment 'may rest upon us, to make us of quick understanding in the fear of the Lord, that we may teach our dear people the good knowledge of the Lord...' (Ryland and Pearce 1796: 25). This was taken up in Samuel Pearce's ordination sermon for Belsher, with Ephesians 4:11 as his text, 'He gave some-pastors and teachers'. Addressing the Silver Street church, Pearce spoke of the incoming minister as Christ's gift to them, declaring, 'you, my brethren, are put in possession of one to-day - a pastor, to feed you with knowledge and understanding' (Ryland and Pearce 1796: 41, italics original), all for the purpose of perfecting the saints for the work of ministry, edifying Christ's body. He continued, 'if he be a teacher, you must be learners; if he have a building to erect, you must be fellow labourers' (Ryland and Pearce 1796: 47).

According to Ryland, since ministers must always be ready to preach, they

must apply closely to study, and unite it with fervent prayer. Understanding is a well-spring of life to him that hath it; but this well is deep, and it is laborious work to draw up these living waters. Clearly to exhibit to our people the great truths of religion, and to point out their salutary tendency, to pacify the conscience, and purify the heart; keeping back nothing that is profitable; but defending the doctrines of the gospel against all opposers, and abusers of them, and guarding our hearers against error on either hand, is no trivial business, which may be performed without exertion or toil. Not only to produce in the pulpit things new and old, but continually to watch over them who are committed to our care, endeavouring, in truly pastoral visits, to water privately, what we have sown in public, requires our utmost diligence (Ryland and Pearce 1796: 26).

Pearce was convinced that the minister's ongoing study is of the highest importance to preaching. In fact, the minister who 'thinks lightly of its value, betrays an ignorance and indolence, which, if indulged, will eventually debase both his character and labours'. 
A studious habit, as you have heard to-day, is essential to a stated minister. A lively imagination may serve an itinerant; but when a man becomes stationary, and preaches three or four times a week to the same people, unless he be industrious in furnishing his mind, his services will soon become insipid, void of solidity, fraught with tautology, and unfit for edification. And what is the result? Why, the thoughtful hearers must either abide with dissatisfaction, or in grief retire; whilst the ignorant are kept in their ignorance, and remain babes, when, under a judicious ministry, they might have become 'fathers in Christ'. (Ryland and Pearce 1796: 51, italics original).

In his history of the English Baptists, Roger Hayden (Hayden 2005: 165) approvingly quotes part of Richard Baxter's saying, which, in full, reads:

If God would but reform the Ministry, and set them on their Duties zealously and faithfully, the People would certainly be reformed: all Churches either rise or fall as the Ministry doth rise or fall, (not in Riches and worldly Grandure) but in Knowledge, Zeal, and Ability for their Work (Baxter 1696, part 1: 115).

Many have held this view. For instance, in his Baptist Union presidential address to the Assembly in 1954, Robert L. Child implicitly agreed with Baxter's dictum, when he lamented 'the absence in many of our people of any real conviction concerning the necessity of a regular trained Ministry'. Infinite pains, he noted, were expended on the equipping of engineers, doctors, and bomber pilots, 'but we seem indifferent to the Church's need of trained leaders', without whom 'how can we expect to prosper?' (Child 1954: 21, italics added). This indifference is reflected, for example, in what I think is an appalling part of the present National Settlement Team's latest 'Draft updated guidelines for ministers profiles 2'. Discussing the expectations of search teams, and under the heading 'Theological Principles, Values and Priorities', it states that 'an Accredited Baptist minister' should 'have a basic grasp of Christian faith and discipleship...' How low is the bar to be set? (Draft updated guidelines for ministers profiles 2016: 3, original italics removed, italics added).

Following his quotation of the original form of Baxter's dictum, Hugh Martin contended that Baxter's The Reformed Pastor 'should be read ... for its statement of the fundamental motives and spirit of the ministerial calling', its two main themes being the minister's oversight of themselves, and their oversight of their congregation, and is based on Acts 20:28 ("Take heed therefore unto yourselves, and to all the flock, over which the Holy Ghost hath made you overseers, to feed the church of God, which he hath purchased with his own blood') (Martin 1954: 153-157).

Key, according to Martin, is what Baxter says about preaching. God cannot use the self-seeker, the preacher of unserious mind, or the one who is 
unfaithful to the call of duty. People will pay no attention to the teaching of one who does not live as they teach 'for all that a minister does is a kind of preaching'.

It is no small matter... to stand up in the face of the congregation and deliver a message as from the living God, in the name of our Redeemer. It is no easy matter to speak so plainly that the ignorant may understand us; and so seriously that the deadest heart may understand us; and so convincingly that contradictory cavillers may be silenced... The great truths are those that men must live upon, and are the instruments of destroying men's sins and raising the heart to God. If we can but teach Christ to our people; we shall teach them all. And all our teaching must be plain and simple, suited to the capacity of our hearers. If you would not teach men, what do you in the pulpit? If you would, why do you not speak so as to be understood? (Martin 1954: 153).

Similar convictions appear throughout Baptist history. In making the case for an educated ministry, the founders of the Bristol Education Society appealed to history and God's normal means of working in and through his church.

Consult the history of the church, and you will uniformly find through every period of it, with very few exceptions, that those ministers who have been the most laborious and successful in their work, have been as eminent for sound learning, as for substantial piety. Nor is it to be doubted but that, whenever there is a revival of religion amongst us, men will be raised up, not only eminent for spiritual gifts, but who will endeavour zealously to improve those gifts, for the attainment of all that knowledge, which, with the blessing of God, may render them able ministers of the new testament. For though we have no sort of doubt but that the great Head of the church could, if he pleased, carry on his work, not only without learned ministers but without any ministers at all; yet as he sees fit, for the most part, to fulfil his designs in the use of means, it is in this way we are to expect his presence and blessing (An Account of the Bristol Education Society 1770: ix, italics original).

My own minister at New Road Baptist Church, Bromsgrove, Keith Blades, said: 'Few things are more precious and persuasive than an intelligent mind, fired by the Holy Spirit and fuelled from the reservoir of the wisdom of God' (Cross 1980s).

Leonard Champion was convinced that there could be no renewal of the church without serious biblical and theological renewal. In the late eighteenth century, this was evidenced in the emphasis placed on learning combined with use of the biblical languages, the study of theology, church history, philosophy, and the other arts and sciences. It was not about intellectual achievement, but about learning more of God, his world, and his ways in the world, for the purpose of making the gospel known within the churches 
and on the mission field-domestic and foreign. While this was the duty of all believers, it was especially so of the ministers who led the way as those entrusted with the preaching of the word, and pastoral care of the people. Times of revival have always involved new ways of theological thinking, the combination of heart and mind, right belief and faithful action (Champion 1980; cf. Cross 2017).

The centre of all Baptist life has always been theology. Faith precedes practice: it always has, it always should (The Baptist Doctrine of the Church 1948: 442). This is so for all believers, for we are all disciples of Christ, but it is especially so for ministers, those whom God calls and equips as ministers of the gospel, pastors of his flock. 'From everyone to whom much has been given, much will be required; and from one to whom much has been entrusted, even more will be demanded' (Luke 12:24, NRSV). Sidlow Baxter's opening statements in the 'Introduction' to his survey of the Bible states:

No man's education is complete if he does not know the Bible. No Christian minister is really qualified for the ministry of the Christian Church without a thorough study of the Bible. No Christian worker can be fully effective without a ready knowledge of the Bible. No Christian believer can live the Christian life to the full without an adequate grasp of the Bible (Baxter 1966: 9).

\section{Conclusion}

The research presented here, and particularly in the book on which it is based (Cross 2016), offers a detailed, referenced, and sourced study which sets out to refute the claims that Baptists came late and unevenly to the position that theological education is essential to a vital ministry, and that it is as essential to the health and well-being of the churches and their mission today as it has ever been. It also seeks to provide evidence that the comparative neglect of Baptist scholarship and scholarly contributions to the various theological disciplines in biblical and historical surveys is evidence more of the shallowness, and at times presumption, of authors, and a lack of rigour on their part, than the absence of a substantial body of Baptist scholarly work. In addition, it sets out to show Baptists how central the study of the Bible and theology has been, and should continue to be, in the preparation of ministers.

It also sets out to provide an apologetic for the recovery of theology to its central role in the preparation of men and women for ministry, and various works of service (Ephesians 4:12) in the church and the world today. No further justification, I believe, should be needed than the New Testament exhortations of those to whom has been entrusted the Christian tradition 'through many witnesses' which they are to 'entrust to faithful people who will be able to teach others as well' (2 Timothy 2:2). Part of this is that we are to do our best to present ourselves to God as those approved by him, 
workers who have no need to be ashamed, 'rightly handling the word of truth' (2 Timothy 2:15). No one can rightly handle or use something they simply do not understand. It is absolutely correct to state that 'to communicate simply you must understand profoundly'.

\section{Bibliography}

An Account of the Bristol Education Society: Began Anno 1770 (1770). Bristol: W. Pine.

Annual Paper concerning the Lord's Work... 1870 (1870). In Bebbington DW (1996) 'Spurgeon and British Evangelical Theological Education'. In Hart DG and Mohler RA Jr (eds) Theological Education in the Evangelical Tradition. Grand Rapids, MI: Baker Books, pp. 217-34.

Bass CC (2013) Thomas Grantham (1633-1692) and General Baptist Theology. Centre for Baptist History and Heritage Studies, 10. Oxford: Regent's Park College.

The Baptist Doctrine of the Church (1948). Baptist Quarterly 12(12): 440-48.

Baxter JS (1966) Explore the Book. Grand Rapids, MI: Zondervan.

Baxter R (1696) Reliquice Baxteriane. London: T. Parkhurst, J. Robinson, J. Lawrence, and J. Dunton.

Carey W (1792) An Enquiry into the Obligations of Christians, to use Means for the Conversion of the Heathens. Leicester: Ann Ireland, J. Johnson, T. Knott, R. Dilly, and Smith.

Champion LG (1980) Evangelical Calvinism and the Structures of Baptist Church Life. Baptist Quarterly 28(5): 196-208.

Child RL (1954) The Church's Commission To-Day. London: the Carey Kingsgate Press.

Clipsham EF (n.d.) Ryland, John (1753-1825), Baptist minister and theologian. Oxford Dictionary of National Biography Online, Oxford University Press, 2004. http://ezproxyprd.bodleian.ox.ac.uk:2167/view/article/24412 (Accessed 20 January 2015).

Colwell JE (2005) Promise and Presence. Milton Keynes: Paternoster.

Crosby T (1738-40) The History of the English Baptists, 4 volumes. London: For the Editor.

Cross AR (1980s) Commonplace book, manuscript in author's possession.

Cross AR (2016) To Communicate Simply You Must Understand Profoundly: Preparation for Ministry among British Baptists. Didcot: The Baptist Historical Society.

Cross AR (2017) Useful Learning: Neglected Means of Grace in the Reception of the Evangelical Revival among English Particular Baptists. Eugene, OR: Pickwick Publications.

Culross J (1897) The Three Rylands. London: Elliot Stock. 
Draft updated guidelines for ministers profiles 2_2016 (2016). Didcot: Baptist Union of Great Britain.

Edward Terrell's Charity (n.d.) In Manchee TJ (ed) The Bristol Charities, volume 1. Bristol: T. J. Manchee, pp. 280-84.

Essick JI (2013) Thomas Grantham. The James N. Griffith Series in Baptist Studies. Macon, GA: Mercer University Press.

Evans C (1770) An Address to the Students in the Academy at Bristol, April 12, 1770. In Rippon J (1790-1802) The Baptist Annual Register, 4 volumes, s.l.: s.n., volume 1, pp. 345-51.

Evans C (1775) The Kingdom of God. Bristol: W. Pine, T. Cadell, M. Ward / London: G. Keith, J. Buckland, and W. Harris.

Evans C (1779) The Law Established by the Gospel. Bristol: W. Pine.

Evans C (1781) Elisha's Exclamation! Bristol: W. Pine.

Evans H ([1773]) The Able Minister. Bristol: W. Pine, T. Cadell, M. Ward, S. Edwards / London: G. Keith and J. Buckland.

Firmin G (1688) Scripture-Warrant Sufficient Proof for Infant-Baptism. London: Tho. Parkhurst.

Gill J (1769) A Body of Doctrinal Divinity, 2 volumes. London: For the Author. Hayden R (2005) English Baptist History and Heritage, 2nd edition. Didcot: The Baptist Union of Great Britain.

Leonard BJ (2003) Baptist Ways: a History. Valley Forge, PA: Judson Press.

Martin H (1954) Puritanism and Richard Baxter. London: SCM Press.

Milne DB (1982) Know the Truth. Leicester: Inter-Varsity Press.

Moon NS (1979) Education for Ministry: Bristol Baptist College 1679-1979. Bristol: Bristol Baptist College.

Murray S (2004) Post-Christendom: Church and Mission in a Strange New World. Carlisle: Paternoster Press.

Randall IM (2000) Educating Evangelicalism. Carlisle: Paternoster Press.

Randall IM (2005) A School of the Prophets. London: Spurgeon's College.

Randall IM (2007) A Mode of Training: a Baptist Seminary's Missional Vision. Transformation 24(1): 2-13.

Ryland J (1812) Advice to Young Ministers, respecting their preparatory Studies. Bristol: E. Bryan.

Ryland J and Pearce S (1796) The Duty of Ministers to be nursing Fathers to the Church; and the Duty of Churches to regard Ministers as the Gift of Christ. s.l.: s.n.

Ryland J (n.d.) J. Rylands Hebrew Notes on Psalms 1 and 23. MS in the Bristol Baptist College Library, OS G 95 A 16031.

Ryland JC (1777) A Key to the Greek New Testament. London: George Keith, and Edward and Charles Dilly.

Spurgeon CH (1874) Being the Address delivered by C. H. Spurgeon, at the College Conference, on Tuesday Morning, April 14, 1874, in The Com- 
plete Works of C. H. Spurgeon, volume 83: The Sword EO The Trowel, volume 4. Ebook, s.l.: Delmarva Publications, 2013, originally in The Sword and the Trowel (May, 1874).

Spurgeon CH (1882) Report of the Pastors' College, 1881-82. In Spurgeon CH (ed) The Sword and the Trowel, April 1882. http://gracebooks.com/library/index.php?dir=Charles\%20Spurgeon/ (Accessed 8 August 2013).

Spurgeon CH (1887) What we aim at in the Pastors' College. In Annual Paper concerning the Lord's Work in connection with the Pastors' College Newington, London. 1886-87. [London]: Alabaster, Passmore, and Sons, pp. 3-10.

Spurgeon CH (1889) Report of Pastors' College, 1888-9. In The Sword and the Trowel, 1889. London: Passmore \& Alabaster.

Spurgeon CH (1962) Autobiography: The Early Years 1834-1859, volume 1. London: The Banner of Truth Trust.

Spurgeon CH (2013) The Complete Works of C. H. Spurgeon, volume 83: The Swor E The Trowel, volume 4. Ebook, s.l.: Delmarva Publications (2013), originally in The Sword and the Trowel (May, 1874).

Staughton W (1822) Address delivered at the Opening of the Columbian College in the District of Columbia, January 9, 1822. Washington City [DC]: Anderson and Meehan.

Stennett J (1685) Dikduk mikhlol, or, A Comprehensive Grammar. London: S. Roycroft for the Author.

Stetzer E and Im D (2016) Planting Missional Churches. Nashville, TN: B \& H Academic, Kindle edition.

West WMS (1983) To Be a Pilgrim. Guildford: Lutterworth Press.

Whitley WT (1923) A History of British Baptists, 1st edition. London: Charles Griffin. 